$\mathrm{K}$ measured directly and by balance trials was within I0\%, the time seems to have come to ask ourselves seriously whether the mineral balance trial has not had its day.

\title{
REFERENCES
}

Agricultural Research Council: Working Party on Nutrient Requirements of Ruminants (1965). The Nutrient Requirements of Farm Livestock. No. 2. Ruminants. London: HM Stationery Office.

Apfelbaum, M. \& Trémolières, J. (r965). Nutritio Dieta 7, 24r.

Blaxter, K. L. \& Rook, J. A. F. (1957a). F. agric. Sci, Camb. 48, 194.

Blaxter, K. L. \& Rook, J. A. F. (1957b). F. agric. Sci., Camb. 48, 2 10.

Consolazio, C. F., Matoush, LeR. O., Nelson, R. A., Hackler, L. R. \& Preston, E. E. (1962). F. Nutr. 78,78 .

Consolazio, C. F., Matoush, LeR. O., Nelson, R. A., Harding, R. S. \& Canham, J. E. (r963). F. Nutr. 79, 407.

Consolazio, C. F., Matoush, LeR. O., Nelson, R. A., Isaac, G. J. \& Canham, J. E. (I966). Am. F. clin. Nutr. 18, 443 .

Consolazio, C. F., Nelson, R. A., Matoush, LeR. O., Harding, R. S. \& Canham, J. E. (1963). F. Nutr. 79, 399.

Dobson, A., Scott, D. \& Bruce, J. B. (1966). Q. Fl exp. Physiol. 51, 31 I.

Duncan, D. L. (1958). Nutr. Abstr. Rev. 28, 695.

Duncan, D. L. (1966). In Recent Advances in Animal Nutrition. [J. T. Abrams, editor.] London: Churchill.

Ellenberger, H. B., Newlander, J. A. \& Jones, C. H. (1931). Bull. Vt agric. Exp. Stn no. 331.

Ellenberger, H. B., Newlander, J. A. \& Jones, C. H. (1932). Bull. Vt agric. Exp. Stn no. 342.

Ellenberger, H. B., Newlander, J. A. \& Jones, C. H. (1936). F. Dairy Sci. 19, 444.

Ellenberger, H. B., Newlander, J. A. \& Jones, C. H. (1950). Bull. Vt agric. Exp. Stn no. 558.

Freese, H. H. (1958). Arch. Tierernähr. 8, 330.

Helfferich, B., Bauer, R. \& Lenkeit, W. (I965). Z. Tierphysiol. Tierernähr. Futtermittelk. $20,95$.

Hogan, A. G. \& Nierman, J. L. (1927). Res. Bull. Mo. agric. Exp. Stn no. Io7.

Hurwitz, S. \& Griminger, P. (1960). F. agric. Sci., Camb. 54, 373.

Hurwitz, S. \& Griminger, P. (r962). F. Sci. Fd Agric. 13, 185.

Jenkins, N. K. \& Tyler, C. (1960). F. agric. Sci., Camb. 54, I 3 I.

Kaul, A., Jekat, F. \& Starlinger, H. (1965). Int, Z, angew. Physiol. 21, 62.

Kemp, A. (1964). Neth. F. agric. Sci. 12, 263.

Kemp, A. \& Geurink, J. H. (1966). Tijdschr. Diergeneesk. 9r, 580.

Leitch, I. \& Aitken, F. C. (r959). Nutr. Abstr. Rev. 29, 393.

Newlander, J. A., Ellenberger, H. B. \& Jones, C. H. (1936). Bull. Vt agric. Exp. Stn no. 406.

Phillips, G. D. \& Sundaram, S. K. (I966). F. Physiol., Lond. 184, 889.

Wilson, G. M., Olney, J. M., Brooks, L., Myrden, J. A., Ball, M. R. \& Moore, F. D. (1954). Metabolism 3, 324.

\section{A critical evaluation of the mineral and nitrogen balances in man}

\author{
By B. Isaksson and B. Sjögren, Metabolic Ward, Sahlgren's Hospital \\ and University of Göteborg, Göteborg, Sweden
}

The prevalence of certain important errors inherent in the metabolic balance technique (Reifenstein, Albright \& Wells, r945) is well known to workers in the field. Nevertheless, ignorance of this knowledge is not uncommon when interpreting the data (Walker, 1962; Mitchell \& Edman, 1962). As will be shown below, the orthodox definition of the balance as the difference between intake of an element and its excretion with urine and faeces is incomplete. Regardless of this fact, the technique requires as accurate intake and excretion figures as possible, since these figures are usually high compared with the balance. Even a slight error in the intake 
or excretion (or in the analytical procedures) will thus cause a considerable error in the balance calculated, as will be shown below.

\section{The 'constant diet'}

The simple calculation of the nutrient content from food tables can only be acceptable when planning a metabolic diet. The diet must match the patient's previous diet, especially when dealing with elements such as calcium, when adaptation to a new intake level may take months. In order to reduce the number of analyses of the diet it is necessary to put the patient on a constant diet, i.e. a diet consisting of the same food items in the same amounts for a certain number of days, say four periods of 4 days each. Unfortunately, this does not mean that the intake is perfectly constant. On the basis of analyses of twenty-seven different diets, we (Isaksson \& Sjögren, $1965 a$ ) have calculated the distribution of the total error on analytical errors, and errors in preparation as well as variation in composition. The largest error in the intake was caused by day-to-day variation in the composition of the diet. It was not possible to obtain a standard error of the mean intake corresponding to the error in the preparation and analytical procedure without daily analyses. This is a very time-consuming procedure and it is more realistic to rely on a single analysis for every 4-day period. When four samples were taken from each homogenate for analysis, the total standard error of the average was found to be $2 \cdot I, I \cdot 7$, 3.2 , and $2.4 \%$ for nitrogen, calcium, sodium and potassium respectively. At an intake level of $1000 \mathrm{mg} \mathrm{Ca}$, for instance, the calculated intake from the analyses may thus deviate from the real intake by as much as $50 \mathrm{mg}$.

In addition to this random error, there is a systematic error due to returns on trays, pots and pans (Isaksson \& Sjögren, I $965 a, b$ ). Invisible returns will appear even after meticulous scraping with a spatula and these returns cannot be neglected. $\mathrm{I} t$ is therefore necessary to estimate invisible returns by frequent analysis of the dishwater. Mean daily losses of $0.1 \mathrm{~g} \mathrm{~N}$ (range $0-0.2 \mathrm{~g}$ ), $20 \mathrm{mg} \mathrm{Ca}(4-4 \mathrm{I} \mathrm{mg}), 2.7 \mathrm{~m}$ equiv. $\mathrm{Na}(0.2-6 \cdot 7 \mathrm{~m}$-equiv.) and $\mathrm{I} \cdot \mathrm{I} \mathrm{m}$-equiv. $\mathrm{K}(0.4-\mathrm{I} \cdot 7 \mathrm{~m}$-equiv.) have been found. The figures are much higher if the patient does not use the flexible spatula for cleaning plates and glasses (Isaksson \& Sjögren, 1964).

Thus, the concept of a 'constant diet'-so often used in balance reports-should not be misinterpreted.

\section{Quantitative collection of urine and faeces}

When occurring, errors caused by inadequate collection of urine are difficult to demonstrate. A 5-10\% variation in the urinary creatinine excretion is quite common (Isaksson, 1966). This fact reduces the value of creatinine determination as andex of the completeness of urinary collection. The failure to collect all faeces during a metabolic study is also difficult to prove, but gives rise to considerable errors in respect to elements of which the net absorption is small compared to the intake, for instance Ca. The missing of I day's faeces during a $5^{\circ}$-day study at an intake level of $2000 \mathrm{mg} \mathrm{Ca}$ and a true $\mathrm{Ca}$ balance of $+100 \mathrm{mg} /$ day implies an error of about $35-40 \%$ in the calculated balance (Isaksson \& Sjögren, 1965b). 


\section{Miscellaneous systematic errors}

The normal faecal loss on sanitary paper contains about $10 \mathrm{mg} \mathrm{Ca} /$ day but negligible amounts of $\mathrm{N}, \mathrm{Na}$ and $\mathrm{K}$. Corrections for blood withdrawn should not be overlooked (Isaksson \& Sjögren, $1965 b$ ). A change in volume of a sample solution of faecal ash from 10.00 to $9.90 \mathrm{ml}$ due to evaporation during handling could lead to an underestimation of the Ca balance of up to $20-25 \mathrm{mg} /$ day.

\section{Variation in faecal output}

Fig. I $a$, shows a fairly typical result of a $\mathrm{Ca}$ balance study. This situation is typical for all elements for which the net absorption is but a small fraction of the intake, and when an intermittent marker, such as carmine red, has been used for demarcation of faeces. This is not an expression of variation in the absorption of $\mathrm{Ca}$ but reflects irregularities in the bowel movements. It cannot be correct to subject the balance figures of successive periods to statistical treatment as they are interdependent. How will it then be possible to find out the reliability of the mean balance figure? We have introduced the following method (Isaksson \& Sjögren, I 967): In the course of the Ca balance study, the cumulative balance is calculated and expressed in mg per day every time the results of a new period are available (see Fig. I $b$ ). All these different cumulative balances are plotted in a diagram and the dots linked together to form a curve (Fig. Ic).

Rather confusing results are obtained when the method described is applied to the study shown in Fig. 1 . The first two calculations give the impression of a definite negative balance. After the third and fourth periods, the patient seems to have been in balance from period $\mathrm{r}$. Later, the results indicate that the patient has been in a definite positive balance throughout the study, whereas the last periods indicate that the balance has been just slightly positive during the entire study. Depending on the length of the study, quite different results could thus be obtained. Consequently, we have established the following criterion for a reliable calcium balance study: it must be continued until the cumulative balance expressed in $\mathrm{mg} \mathrm{Ca} /$ day does not change appreciably for three to four periods. Our own material of eightyfive studies, comprising the results of 8004 -day periods, has been tested in that way (Isaksson \& Sjögren, I967). To summarize, thirty-five of these studies showed an acceptable cumulative balance curve expressed in $\mathrm{mg} \mathrm{Ca} /$ day, whereas the remaining fifty studies had been completed before the curve levelled off, i.e. it was impossible in all these studies to draw any conclusions as to the true balance. Only a small number of balances lasting less than eight periods ( 32 days) could be approved but, on the other hand, practically all studies lasting for 2 months were acceptable. The method described is an alternative to the use of inert indicators, such as chromium sesquioxide (Whitby \& Lang, I960; Rose, I964). Hargreaves \& Rose (1965) have convincingly demonstrated that in short-term studies, the chromium method should provide a balance value which is considerably closer to the true value than is possible with an intermittent marker. We have had no experience of our own with this method, but have carried out some calculations, shown in Fig. 2. The figure 

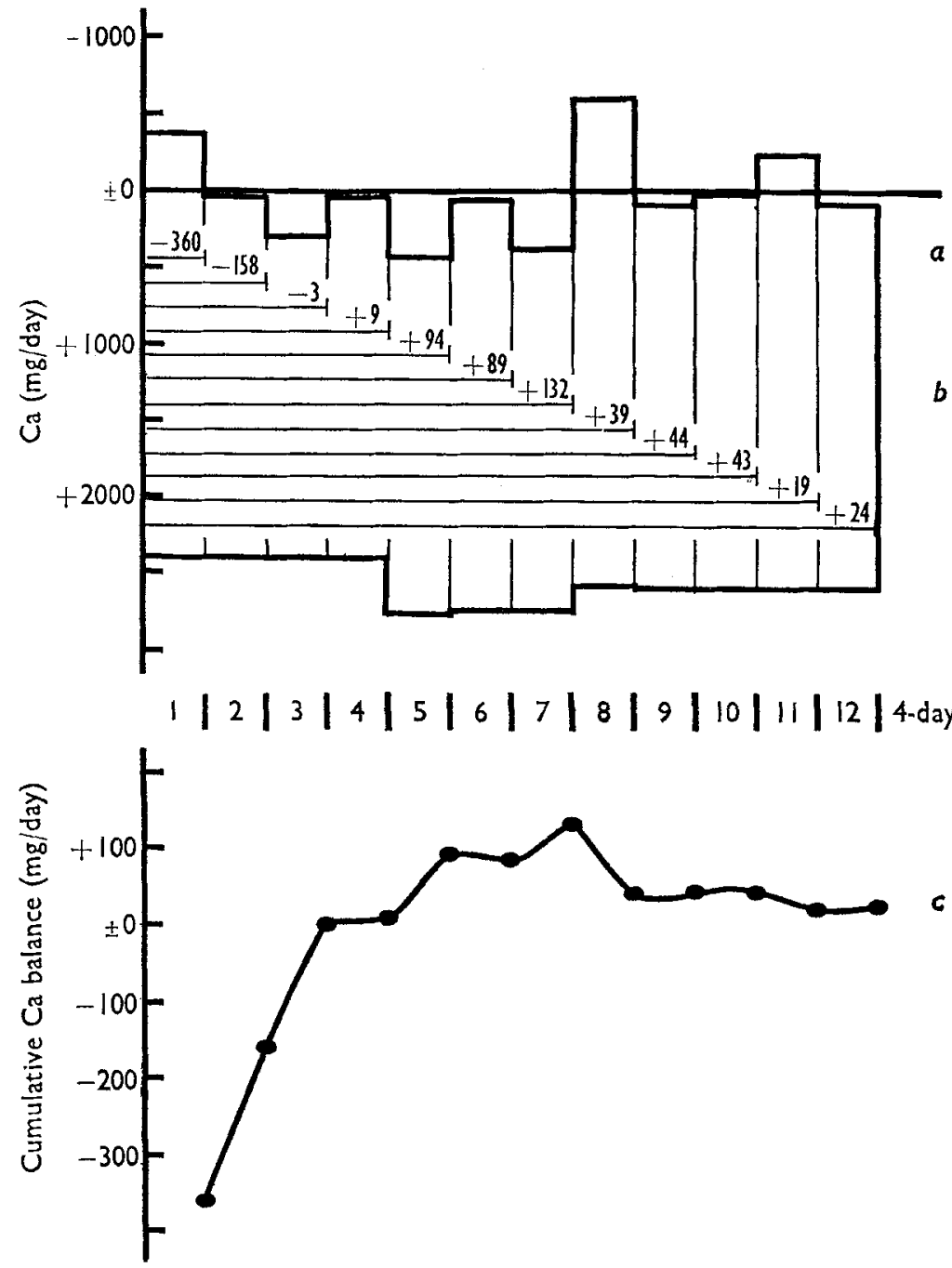

Fig. r. A calcium balance study (patient $\mathrm{M}_{49} \mathrm{D}$, a female $5^{8}$ years old) comprising twelve periods of 4 days each. $a$, charted according to Reifenstein et al. (1945); $b$, successive calculations of the cumulative $\mathrm{Ca}$ balance; $c$, cumulative $\mathrm{Ca}$ balances charted according to the present authors.

shows the error of the calculated balance when the collected faeces contain $80 \%$ of unabsorbed $\mathrm{Ca}$, whereas the simultaneous determinations of chromium show recoveries of 75,8 o or $85 \%$ of the ingested chromium. A deviation of $\pm 5 \%$ from the theoretical value with chromium seems most possible, owing to centrifugal separation in the gut or homogenizer, adherence of chromium to the intestinal wall, or analytical errors. This rather small and undetected deviation thus means an error of up to $\pm 100 \mathrm{mg} \mathrm{Ca} /$ day in the calculated balance.

\section{Dermal losses}

As mentioned above, the definition of a balance as the difference between intake 


$$
\begin{array}{r}
\text { Ca intake } 10000 \mathrm{mg} / 6 \text { days }-\left(\mathrm{Ca}_{\mathrm{u}}+\mathrm{Ca}_{\mathrm{d}} 1800 \mathrm{mg} / 6 \text { days }\right) \\
5000 \mathrm{mg} / 6 \text { days }-(1200 \mathrm{mg} / 6 \text { days })
\end{array}
$$
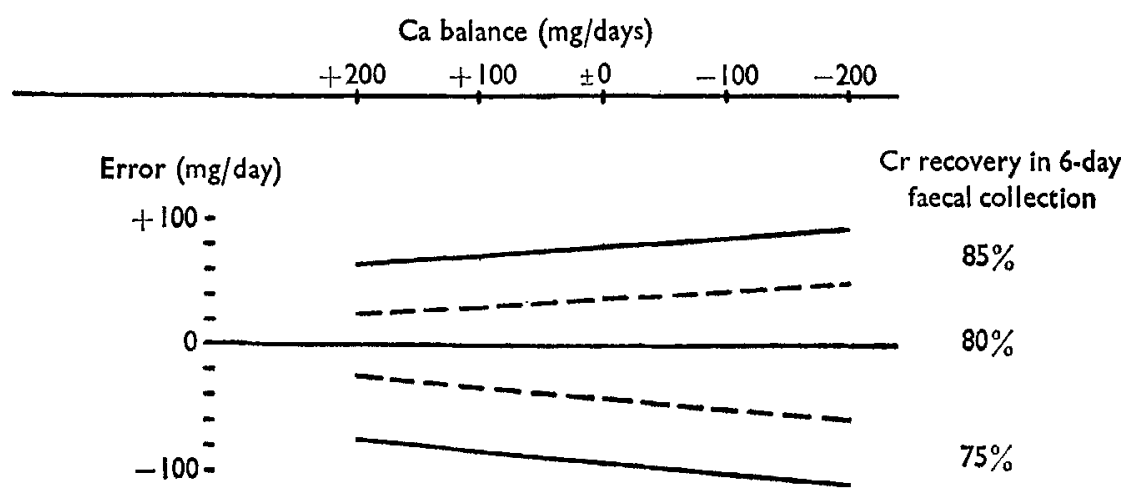

Fig. 2. Errors in 6-day calcium balances calculated from $75-85 \%$ recoveries of an inert indicator $\left(\mathrm{Cr}_{2} \mathrm{O}_{3}\right)$ when the faecal collection contains $80 \%$ of the unabsorbed $\mathrm{Ca}$. — Ca intake $10000 \mathrm{mg} / 6$ days $\left(\mathrm{Ca}_{\mathbf{u}}+\mathrm{Ca}_{\mathbf{d}} \mathbf{I} 800 \mathrm{mg} / 6\right.$ days); - - Ca intake $5000 \mathrm{mg} / 6$ days $\left(\mathrm{Ca}_{\mathbf{u}}+\mathrm{Ca}_{\mathrm{d}} \mathrm{I} 200 \mathrm{mg} / 6\right.$ days).

of an element and its excretion with urine and faeces is incomplete. This will be apparent in a long-term balance study, exemplified by a study which lasted for a whole year (Isaksson, Lindholm \& Sjögren, I967a). After I year, the orthodox cumulative $\mathrm{K}$ balance reached a value of +3255 m-equiv., which-if true-would indicate a total increase in the lean tissue of not less than $27 \mathrm{~kg}$. Judging from the $\mathrm{N}$ balance, which showed an increase of $389 \mathrm{~g}$ in the $\mathrm{N}$ content of the body, the cell mass should instead have increased by $10 \mathrm{~kg}$. The observed weight increase was only $2.7 \mathrm{~kg}$. During the whole study, the cell mass was calculated from the total exchangeable $\mathrm{K}$, measured by means of an isotope dilution technique, as described by $\mathrm{B}$. Lindholm of this laboratory (to be published). The changes in cell mass thus found could not be related to the changes observed in either the $K$ or the $\mathrm{N}$ balance. There must therefore be losses of $\mathrm{K}$ and $\mathrm{N}$ which were not accounted for in the balance, and there is every reason to believe that these occur through the skin. The existence of dermal losses of nutrients has been known for many years. Recently, Consolazio and co-workers (Consolazio, Matoush, Nelson, Hackler \& Preston, 1962; Consolazio, Nelson, Matoush, Harding \& Canham, 1963; Consolazio, Matoush, Nelson, Harding \& Canham, I963), Isaksson \& Sjögren $(1963,1965 b)$ and Isaksson, Lindholm \& Sjögren (1966) have emphasized the fallacy of misinterpretation of balance data if these losses are neglected. It is obvious that neglect of dermal losses during a long-term study leads to unrealistic results. Also in shorter studies, e.g. the first 80 days of the study referred to above, serious misinterpretation may occur. It can be seen from Fig. 3 that during the first eight periods, when the patient actually lost $\mathrm{K}$, the orthodox cumulative balance indicated a slight positive balance. Later when exchangeable $K$ was constant, the cumulative balance showed a gain of body potassium. 


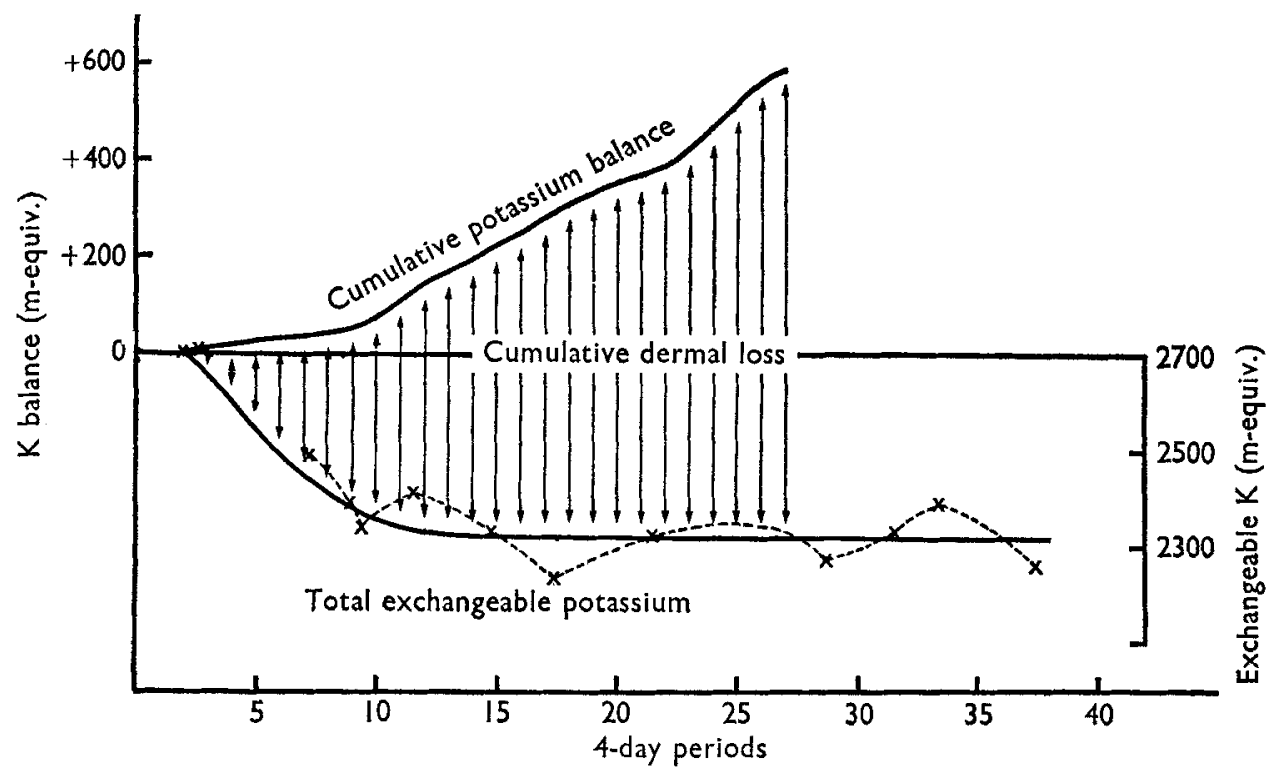

Fig. 3. Cumulative potassium balance and total exchangeable $K$ in the first part of a Imyear study on patient $\mathrm{M}_{5} 6 \mathrm{C}$. The discrepancy is interpreted as due to dermal losses of $\mathrm{K}$. Originally published in Excerpta Medica International Congress Series No. 83, Proceedings of the IInd International Congress of Endocrinology, London, August 1964.

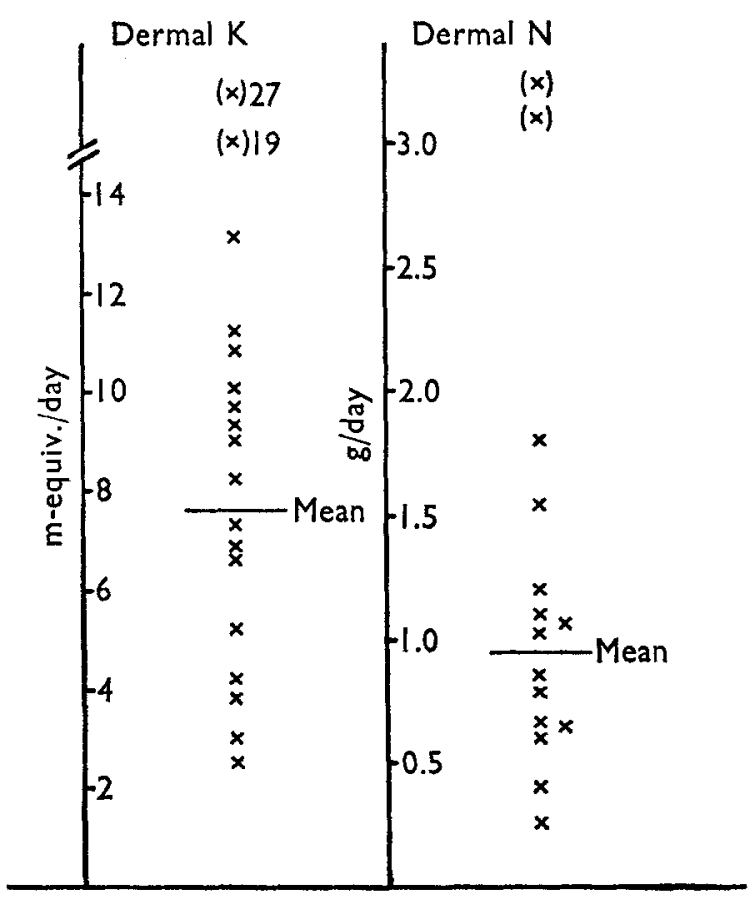

Fig. 4. Daily dermal losses of potassium and nitrogen in eighteen subjects during metabolic balance studies. 
Potassium. We have regularly found discrepancies between the orthodox cumulative $\mathrm{K}$ balance and changes in total exchangeable $\mathrm{K}$. The dermal losses have been calculated from this discrepancy between two expressions for changes in body $\mathrm{K}$ (Isaksson \& Sjögren, ${ }^{196}{ }_{3}$ ). We have found the dermal losses of $\mathrm{K}$ to amount to $2 \cdot \mathrm{5}^{-}$ I3 m-equiv./day (average $7.5 \mathrm{~m}$-equiv./day) in sixteen subjects, with two other observations of 19 and 27 m-equiv./day (Fig. 4). In earlier reports, direct analysis of sweat has been used for measurement of the daily dermal losses of $\mathrm{K}$. The results usually show ranges below our mean value (Freyberg \& Grant, 1937; Keutmann, Bassett \& Warren, 1939; Arn \& Reimer, 1950) or are found below our lowest value (Dahl, Stall \& Cotzias, I955; Gitelman \& Lutwak, 1963; Schwartz, Chokas \& Panariello, 1964).

Nitrogen. Changes in the total exchangeable $\mathrm{K}$ and the orthodox cumulative $\mathrm{N}$ balance measured at the same time can be used to calculate dermal losses of $\mathrm{N}$ if there is a constant relation between $\mathrm{K}$ and $\mathrm{N}$ in the body. This assumption is valid in most instances, and the relation is estimated to be 3 m-equiv. $\mathrm{K} / \mathrm{g} \mathrm{N}$ (Elkin-
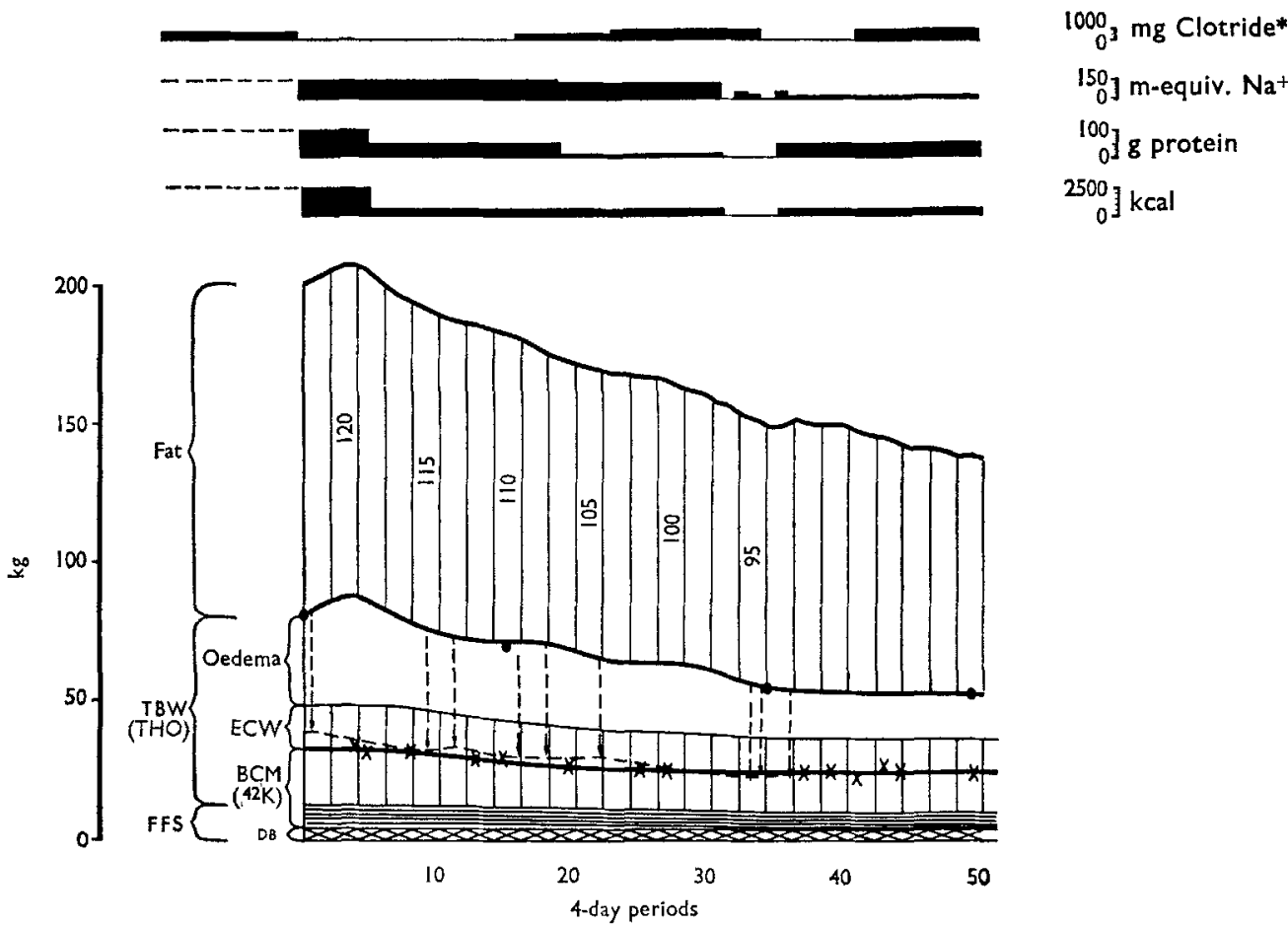

Fig. 5. Changes in body cell mass (BCM), total body water (TBW) and its partition (intracellular, extracellular (ECW) and oedema), and body fat during a weight-reducing regimen in an extremely obese woman (patient $\mathrm{M}_{77} \mathrm{~A}$ aged 44 years). All the values were calculated by isotope dilution methods and body-weight measurements. Dashes refer to calculations from ${ }^{24} \mathrm{Na}$ or ${ }^{82} \mathrm{Br}$ measurements. FFS, fat-free solids comprising body cell protein mass and dry bone mass (DB), the latter including other extracellular solids and assumed to vary insignificantly during the study.

*Merck Sharp \& Dohme (chlorothiazide). 
ton \& Danowski, 1955; Bergström \& Hultman, I966). The second column in Fig. 4 shows dermal losses of up to $2 \mathrm{~g} /$ day, the mean value being close to $\mathrm{I} \cdot \mathrm{O} \mathrm{g} /$ day. Neglecting this amount may lead to faulty conclusions, not least when evaluating the effect of anabolic treatment, as recently illustrated (Isaksson \& Sjögren, ${ }_{196} b$; Isaksson, Lindholm \& Sjögren, I967a).

We suggest that in long-term studies the orthodox balance methods for $\mathrm{N}, \mathrm{K}$, (and $\mathrm{Na}$ ) be replaced by isotope dilution methods, primarily ${ }^{42} \mathrm{~K}$, tritium-labelled water and ${ }^{24} \mathrm{Na}$ or ${ }^{82} \mathrm{Br}$. Repeated measurements during the study will enable us to calculate and follow changes in body cell mass, extracellular water and body fat, as illustrated in Fig. 5.

Calcium. Dermal losses of $\mathrm{Ca}$ cannot be measured by a technique of the kind described above for estimation of dermal losses of $\mathrm{K}$ and $\mathrm{N}$. At present it appears necessary to collect sweat in some form or other for analysis. It would, however, be difficult to collect all the sweat produced by a person during $24 \mathrm{~h}$ without affecting the perspiration rate. Therefore, we (Isaksson, Lindholm \& Sjögren, I967b) have investigated the possibility of calculating dermal losses from the expression $(\mathrm{Ca}: \mathrm{K})_{\text {sweat }} \times \mathrm{K}_{\text {derm }}$, where $\mathrm{K}_{\text {derm }}$ is estimated as described above, and the $\mathrm{Ca}: \mathrm{K}$ ratio is determined on a sweat sample collected in a plastic bag from the arms during $\mathrm{I} h$. Our studies have shown that there is a remarkably good correlation between the $\mathrm{Ca}: \mathrm{K}$ ratio in sweat from the arms and that of sweat from the entire body. The ratio of $\mathrm{Ca}: \mathrm{K}$ in arm sweat varies from day to day, but it is easy to obtain a sufficient number of observations for calculation of a representative mean value. Analyses of skin grafts have indicated that most $\mathrm{Ca}$ and $\mathrm{K}$ are lost by perspiration and not by desquamation. Fig. 6 shows the $\mathrm{Ca}: \mathrm{K}$ ratio and $\mathrm{Ca}_{\text {derm }}$ in twenty-one studies. The daily dermal loss of $\mathrm{Ca}$ varied between $20-365 \mathrm{mg}$. The right-hand part of Fig. 6 shows how corrections for the estimated dermal losses affect the balances in the eleven subjects for whom an otherwise acceptable $\mathrm{Ca}$ balance had been obtained. The positive balances in studies $\mathrm{M}_{5} 6 \mathrm{C}_{-4}, \mathrm{M}_{5} 6 \mathrm{C}_{-5}$ and $\mathrm{M}_{93}$ were more or less eliminated. The slightly negative balances in studies M66-2 and M83 were changed into more negative ones. After correction, the last four subjects showed a pronounced negative balance, whereas in the uncorrected state, they varied from clearly positive $\left(\mathrm{M}_{77-3}\right)$ to equilibrium $\left(\mathrm{M}_{77-1}\right)$, slightly negative $\left(\mathrm{M}_{\mathrm{I}} 6 \mathrm{~B}\right)$ or clearly negative $\left(\mathrm{M}_{49} \mathrm{~F}\right)$. (Data from Isaksson et al. $1967 b$.)

\section{Theoretical P balance}

The theoretical $\mathrm{P}$ balance has often been calculated from the simultaneous $\mathrm{Ca}$ and $\mathrm{N}$ balances in order to discover gross errors or to 'emphasize any situation where the measured balances differ from the theoretical' (Reifenstein et al. 1945). According to earlier studies (Mitchell \& Hamilton, 1949; Consolazio, Matoush et al. 1963; Gitelman \& Lutwak, 1963) and our own (Isaksson \& Ohlsson, 1967) the dermal loss of $P$ seems to be negligible. Thus, the actual $P$ balance would never tally with the theoretical $\mathrm{P}$ balance calculated from orthodox balances of $\mathrm{Ca}$ and $\mathrm{N}$, i.e. when dermal losses of these elements have not been taken into account, and when the study has not been of sufficient duration to minimize the error in the $\mathrm{Ca}$ balance 


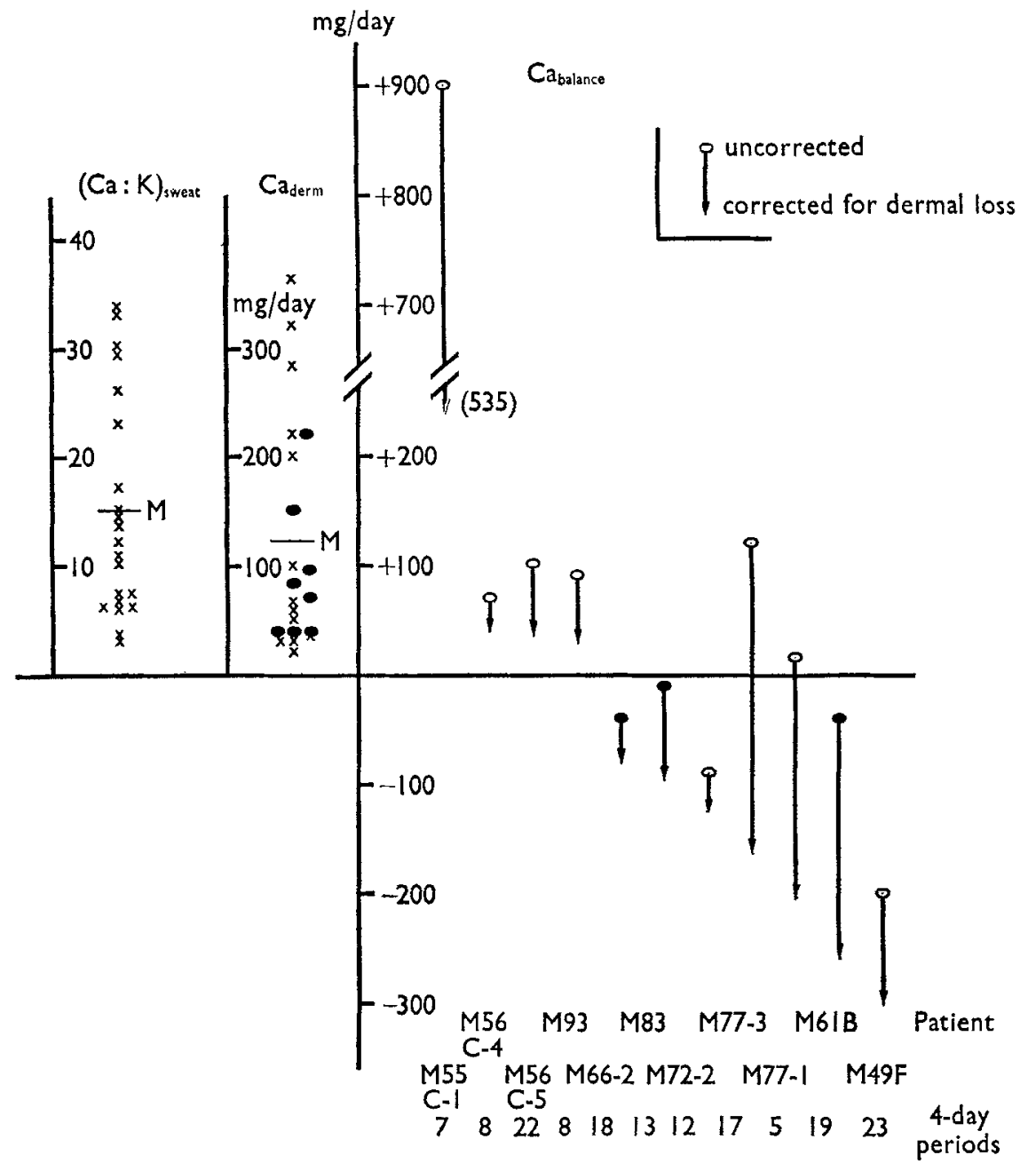

Fig. 6. Individual mean $(\mathrm{Ca}: \mathrm{K})_{\text {sweat }}$ ratios and corresponding dermal calcium losses (Caderm) in twenty-one subjects, as well as their significance for the $\mathrm{Ca}$ balance in the eleven subjects, for whom an otherwise acceptable balance had been obtained. Data from Isaksson, Lindholm \& Sjögren (1967b). - subjects for whom the Caderm has been calculated from an estimated value of $K_{\text {derm }}$ of $6.5 \mathrm{~m}$ equiv./day.

due to variation in faecal output. In the reports which show satisfactory agreement despite this fact, the studies have usually been of short duration and the agreement has probably been coincidental. In more prolonged studies, as reported in the literature, the theoretical $\mathrm{P}$ balance has often exceeded the observed balance. This has also been so in practically all the studies carried out at our laboratory (Isaksson \& Ohlsson, I967). Fig. 7 shows that the $P$ balance determined agreed much more closely with the theoretical $\mathrm{P}$ balance, calculated from corrected balances of $\mathrm{Ca}$ and $\mathrm{N}$, than with balances not subject to correction. 


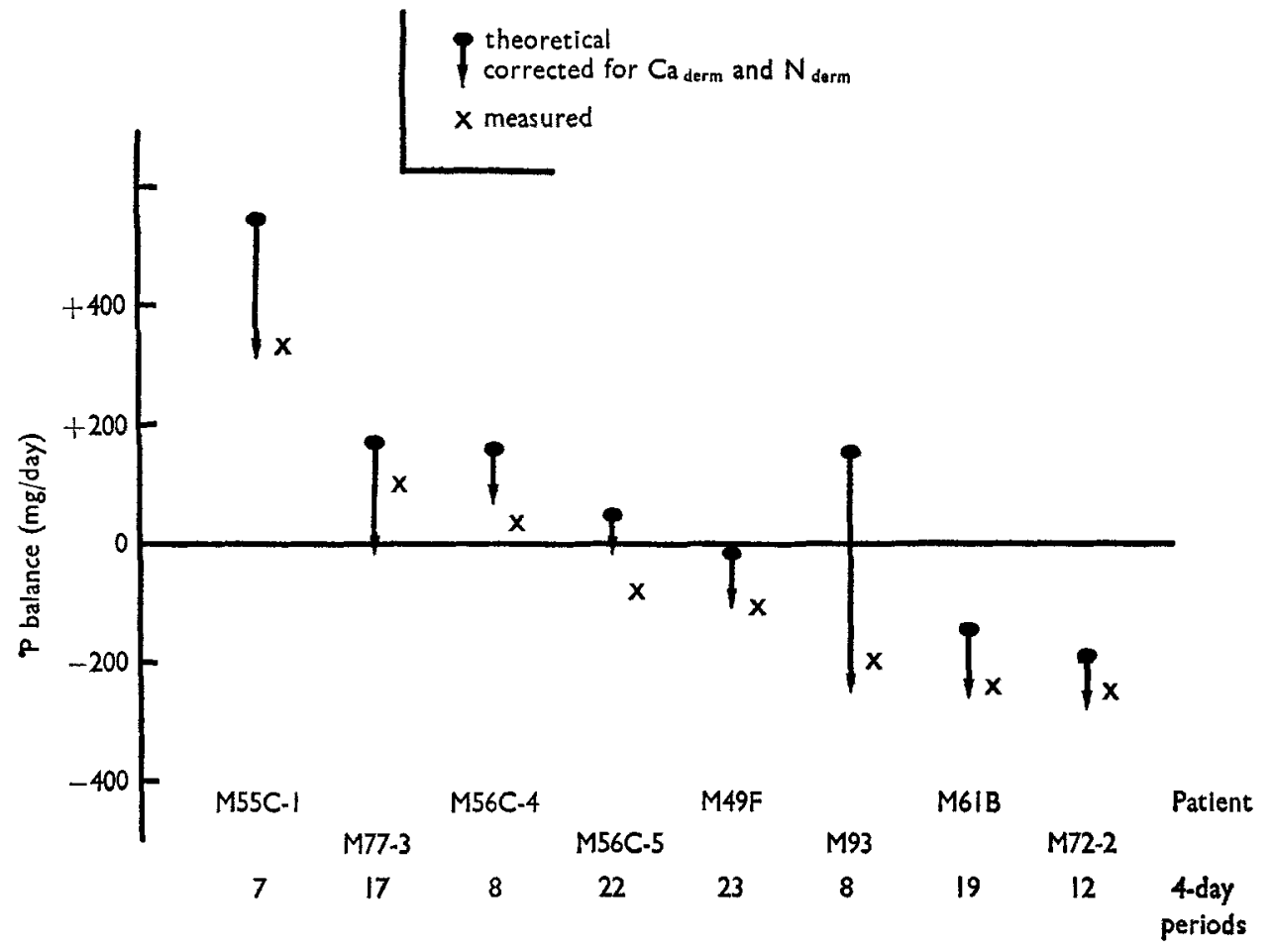

Fig. 7. Comparison between measured phosphorus balances and theoretical phosphorus balances calculated with and without corrections for dermal losses of calcium and nitrogen in eight subjects. (Data from Isaksson \& Ohlsson, 1967).

\section{Conclusions}

In conclusion, there are many errors inherent in the metabolic balance technique, which limit the usefulness of the method and cast doubt on the validity of many studies published in the literature. We are of the opinion that due account must be taken of these errors in all metabolic balance studies and when possible the balance technique should be replaced by isotope dilution methods.

Our own studies referred to in the text were supported by grants from The Swedish Medical Research Council (project I9X-570).

\section{REFERENCES}

Am, K. D. \& Reimer, A. (1950). \%. clin. Invest. 29, 1342.

Bergström, J. \& Hultman, E. (1966). Scand. F. clin. Lab. Invest. 18, 16.

Consolazio, C. F., Matoush, LeR. O., Nelson, R. A., Hackler, L. R. \& Preston, E. E. (1962). F. Nutr. 78,78 .

Consolazio, C. F., Matoush, LeR. O., Nelson, R. A., Harding, R. S. \& Canham, J. E. (1963). F. Nutr. 79, 407 .

Consolazio, C. F., Nelson, R. A., Matoush, LeR. O., Harding, R. S. \& Canham, J. E. (เ963). F. Nutr. 79, 399.

Dahl, L. K., Stall, III, B. G. \& Cotzias, G. C. (1955). F. clin. Invest. 34, 462.

Elkinton, J. R. \& Danowski, T. S. (1955). The Body Fluids. Baltimore: The Williams \& Wilkins Company. 
Freyberg, R. H. \& Grant, R. L. (1937). F. clin. Invest. 16, 729.

Gitelman, H. J. \& Lutwak, L. (1963). Clin. Res. II, 42.

Hargreaves, T. \& Rose, G. A. (1965). Clin. Sci. 28, 537.

Isaksson, B. (1 966). Fourth European Symposium on Calcified Tissues, Leiden/Noordwijk aan Zee, p. 59.

Isaksson, B., Lindholm, B. \& Sjögren, B. (1966). Acta med. scand. Suppl. 445, p. 26.

Isaksson, B., Lindholm, B. \& Sjögren, B. (1967a). Metabolism 16, no. 2.

Isaksson, B., Lindholm, B. \& Sjögren, B. (1967b). Metabolism 16, no. 4.

Isaksson, B. \& Ohlsson, L. (1967). Metabolism 16, no. 4.

Isaksson, B. \& Sjögren, B. (1963). Scand. F. clin. Lab. Invest. 15, Suppl. 69, p. 108.

Isaksson, B. \& Sjögren, B. (1964). Nord. Med. 71, 616.

Isaksson, B. \& Sjögren, B. (1965a). Nutritio Dieta 7, I75.

Isaksson, B. \& Sjögren, B. (1965b). Proc. int. Congr. Endocr. II. London, 1964, p. 1041.

Isaksson, B. \& Sjögren, B. (1967). Metabolism 16, no. 4.

Keutmann, E. H., Bassett, S. H. \& Warren, S. L. (1939). F. clin. Invest. 18, 239.

Mitchell, H. H. \& Edman, M. (1962). Am. F. clin. Nutr. 10, 163.

Mitchell, H. H. \& Hamilton, T. S. (1949). F. biol. Chem. 178, 345 .

Reifenstein, E. C. Jr, Albright, F. \& Wells, S. L. (I945). F. clin. Endocr. 5, 367.

Rose, G. A. (1964). Gut 5, 274.

Schwartz, E., Chokas, M. V. \& Panariello, V. A. (1964). Am. F. Med. 36, 233.

Walker, A. R. P. (1962). Am. F. clin. Nutr. ro, 95.

Whitby, L. G. \& Lang, D. (1960). F. clin. Invest. 39, 854 .

\section{Nitrogen balances}

\section{By EDwIN C. Owen, Biochemistry Department, Hannah Dairy Research Institute, Ayr}

Duncan (1958), Hegsted (1964) and Martin (1966) noted that published balances of certain nutrients can be so positive as to imply larger retentions than those calculable from carcass analyses. Nevertheless balances of chromium sesquioxide $\left(\mathrm{Cr}_{2} \mathrm{O}_{3}\right)$ (Chanda, Clapham, McNaught \& Owen, 195I) and of borate (Owen, 1942-4), which we quantitatively recovered from the diet (Fig. I) are not subject to this criticism. Fig. 2, which records graphically information from the paper of Owen, Smith \& Wright (1943), who demonstrated that urea can be substituted for protein, shows the output of nitrogen by cows as a function of their $\mathrm{N}$ intake. In these experiments the diet was of concentrate meal and hay which required separate 2-day analyses, and the output was urine plus faeces plus milk. Refusals of meal or hay were measured. In Fig. 2 the heights of some of the ordinates above the line of equilibrium, indicate retentions of $\mathrm{N}$ which might at first sight seem unacceptably large. Two questions, therefore, arise: (I) how large a positive balance is physiologically admissible, and (2) if the balances are inadmissibly large, from what technical imperfections could they have arisen?

\section{Question (I)}

The 1943 experiment was done during the war when cattle food was rationed, and on a farm where the ration coupons were returned in order to find out whether wartime self-sufficiency was feasible. Before the experiment, therefore, these cows had been undernourished. Moreover, as a result of many years of $\mathrm{N}$ balance experiments on milch cows, the Institute had recommended a lower $\mathrm{N}$ allowance than was customary (Owen, r94I). Fig. 3 is a similar graph from a later experiment 